\title{
Elicitor Effect of Chitosan on In Vitro Culture of Different Explants of Physalis Accessions From East Java
}

\author{
Retno Mastuti1,** Jati Batoro², Budi Waluyo ${ }^{3}$ \\ ${ }^{1}$ Biology Department, Faculty of Mathematics and Natural Sciences, Brawijaya University, Malang, Indonesia \\ ${ }^{2}$ Biology Department, Faculty of Mathematics and Natural Sciences, Brawijaya University, Malang, Indonesia \\ ${ }^{3}$ Agronomy Department, Faculty of Agriculture, Brawijaya University, Malang, Indonesia \\ *Corresponding author. Email: mastuti7@ub.ac.id
}

\begin{abstract}
Chitosan is a natural molecule derived from arthropods and fungi that can stimulate many physiological responses in plants. Chitosan had also shown positive effect on in vitro shoot regeneration. Therefore, this research aims to observe the response of shoot growth of in vitro Physalis plant accessions obtained from several areas in Madura Island and East Java on chitosan effect. Two types of explants shoot tips and in vitro nodal explants for each Physalis plant accession were cultured on elicitation medium (MS basal medium supplemented with BAP $2 \mathrm{mg} / 1$ and IAA $0.05 \mathrm{mg} / \mathrm{l})$ containing chitosan elicitor $(0,75,125 \mathrm{mg} / \mathrm{l})$. The number and height of shoots were observed weekly for six weeks. The results showed that both types of explants from all accessions were able to regenerate and multiply shoots however shoot tip explants showed better growth. A2 accessions from Madura Sampang was able to regenerate shoots in high a number than other accessions on chitosan concentration of $125 \mathrm{mg} / 1$. These results provide a future prospect to study synthesis of secondary metabolites in Physalis accession induced by chitosan elicitors.
\end{abstract}

Keywords: accession, chitosan, elicitors, Madura, Physalis

\section{INTRODUCTION}

The genus Physalis is one of the largest genera of the Solanaceae family which is not only used as food but also used as traditional medicine [1]. The medicinal benefits of Physalis plants are due to various biological and pharmacological activities associated with the presence of flavonoids, phenyl propanoids, alkaloids, physical, withanolides, and other bioactive compounds [2]. Withanolides, a class of lactone steroids, has been known for its antitumor, and anti-inflammatory properties [(3].

Until now, several Physalis accessions have been identified from various regions in Indonesia, such as the Surakarta Residency (18 accessions) [4], West Sumatra (31 accessions) [5], East Java, Central Java, and West Java [6]. Each accession can describe the diversity that exists in a certain plant population related to environmental conditions.
Plants that are sessile have a self-defense strategy involving the biosynthesis of secondary compounds. Therefore, the synthesis of secondary compounds is strongly influenced by the environment. However, plant secondary metabolites that are synthesized at certain physiological and developmental stages are also produced in very small amounts, namely less than $1 \%$ dry weight [7]. This is a weakness in the use of medicinal ingredients which must be available in large quantities. In vitro culture system is an alternative to produce secondary metabolites because the organs that are grown in vitro can be stimulated to produce secondary compounds in higher level and sometimes have different profiles with mother plants.

Production of secondary compounds in vitro have been frequently induced by elicitation methods [811]. Secondary metabolites in plants act as communication signals in response to unfavourable conditions such as pathogenic infections and environmental stresses [12]. 
Physalis angulata seeds soaked in chitosan elicitor were able to regenerate shoots and showed good in vitro growth. In addition, the levels of withanolide compounds produced by in vitro shoots are also higher than shoots treated with PEG elicitors [13]. This study aims to determine the elicitor effect of chitosan on in vitro shoot growth of different types of explants from several Physalis accessions collected from Madura Island and several regions in East Java.

\section{MATERIALS AND METHODS}

\subsection{Plant material}

Accessions of Physalis plants obtained from Sumenep (A1), Sampang (A2 and A4), and Pamekasan (A5) in Madura Island and fom Tulung Agung (B1), Kediri (B3) and Banyuwangi (B5) were the collections of Dr. Budi Waluyo (Department of Agronomy, Brawijaya University).

\subsection{Preparation of explant source}

Sterilization was initiated by shaking the Physalis seeds for 15 minutes in a $20 \%$ commercial bleach solution. Then the seeds are rinsed three times with sterile distilled water for 5 minutes each [14]. Subsequently, the germination of sterile seeds were undertaken in water medium solidified with $10 \mathrm{~g} / \mathrm{l}$ agar without adding nutrients or growth regulators. Two-week old in vitro seedling was ready to be used as a source of explants for shoot induction.

\subsection{Shoot induction}

Cotyledon nodes explants were put on shoot induction medium (MS + BAP $2 \mathrm{mg} / 1$ + IAA 0.05 mg / 1). The resulting adventitious shoots were subcultured at 4 weeks of culture to fresh medium for multiplication. Shoots from the third subculture were subcultured to MS0 medium before transferring to elicitation medium.

\subsection{Elicitation treatment}

Two types of explants, namely shoot tips and nodal explants, were used to see the effect of chitosan elicitor. The shoot tip was cut from the top of the first node. Node explants were taken from the first node after removing the petiole and shoot tips. Each explant was cultured on the elicitation medium, namely MS + BAP $2 \mathrm{mg} / 1$ + IAA $0.05 \mathrm{mg} / 1+$ chitosan $(0,75,125 \mathrm{mg} / \mathrm{l})$. The number of shoot and shoot height were observed every week for 6 weeks.

\section{RESULT AND DISCUSSION}

\subsection{The effect of elicitors on shoot number}

Both explant types, shoots and nodes in vitro from seven Physalis plant accessions (A1, A2, A4, $\mathrm{A} 5, \mathrm{~B} 1, \mathrm{~B} 3$ and B5) showed the ability to induce shoot on MS + BAP medium $2 \mathrm{mg} / 1+$ IAA $0.05 \mathrm{mg}$ / 1 . The resulting adventitious shoots were still able to grow in the medium added with 75 and $125 \mathrm{mg} / \mathrm{l}$ chitosan elicitor. However, each type of explant showed a different response. In general, at four weeks of culture, shoot tip explants showed faster growth than nodal explants either in control medium or in elicitation medium supplemented with chitosan. The regenerated shoots are numerous and larger in size (Figure 1). On the other hand, nodal explant produces shoots with smaller leaf size. Leaf area was not included in the observed parameters due to technical constraints for measuring objects that were still in the in vitro flask.

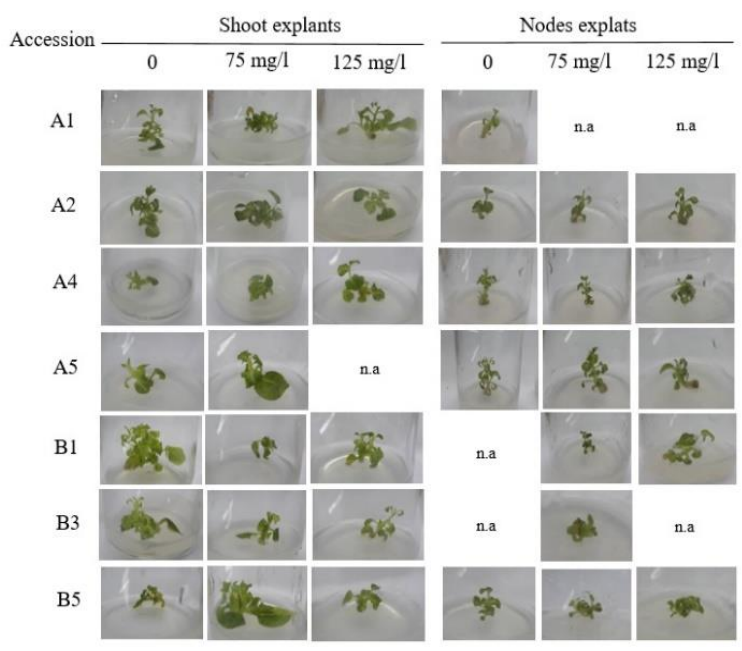

Figure 1 Shoots regeneration of several accessions of P. angulata on four weeks of elicitation medium. A1: Sumenep, A2 and A4: Sampang, A5: Pamekasan, B1: Tulung Agung, B3: Kediri and B5: Banyuwangi. Chitosan concentration: 0,75 and $125 \mathrm{mg} / \mathrm{l}$. n.a = not available data.

Shoot and nodal explants from accessions A1 and A2 produced more shoots than the other five accessions (Figure 2). The highest average number of shoots was $3.75 \pm 1.50$ produced by $\mathrm{A} 1$ accession because of elicitation treatment with $75 \mathrm{mg} / \mathrm{L}$ chitosan. The number of shoots decreased to $1.75 \pm$ $0.50 \mathrm{mg} / 1$ when the elicitor were increased to 125 $\mathrm{mg} / \mathrm{l}$. Whereas A2 accession on $125 \mathrm{mg} / 1$ chitosan elicitation treatment was still able to produce the highest average number of shoots, namely $3.33 \pm$ 1.15 . The number of shoots produced by the other 


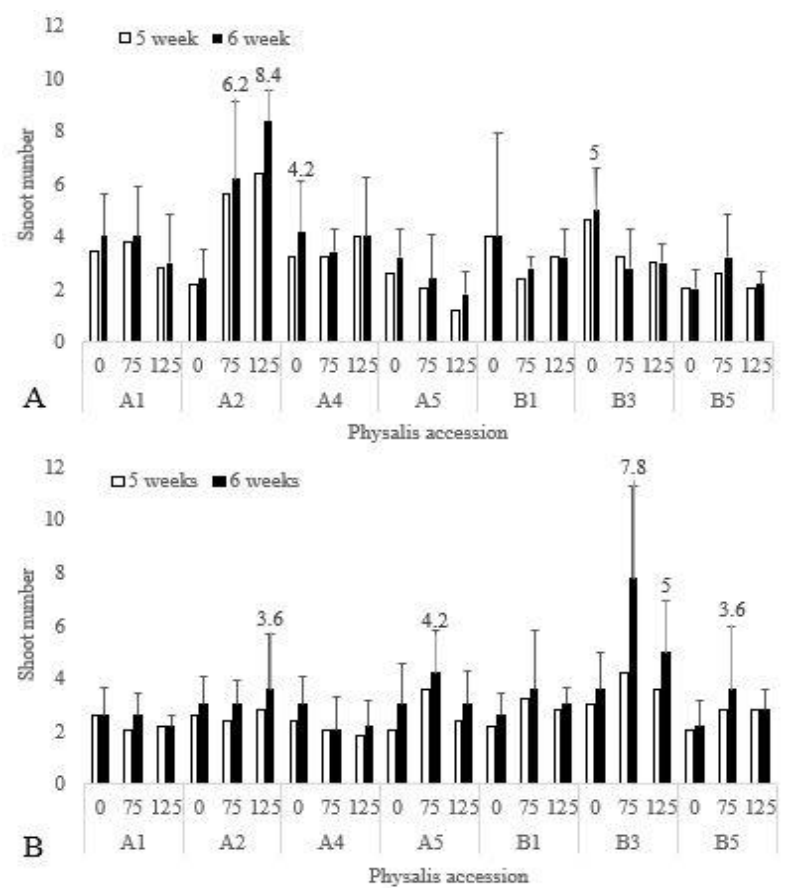

Figure 2. Effect of elicitor chitosan on in vitro shoot number of seven Physalis accession at 5 and 6 weeks after culture. A. Shoot explant, B. Nodal explants. A1: Sumenep, A2 and A4: Sampang, A5: Pamekasan, B1: Tulung agung, B3: Kediri dan B5: Banyuwangi; Chitosan concentration: 0,75 and $125 \mathrm{mg} / \mathrm{l}$.

two accessions (A4 and A5) obtained from Madura Island until the fourth week of culture had not reached three. Node explants in all accessions showed lower growth capability. Until the fourth week of culture all accessions only produced less than two shoots.

Sixth week after culture, the average number of shoots produced by the nodal explants tended to be less, ranging from $2.2 \pm 0.98$ to $7.8 \pm 3.48$ (Figure 2). Whereas the number of shoots produced by shoot tip explants ranged from $1.8 \pm 0.83-8.4 \pm 1.14$. The existence of chitosan elicitor did not always reduce the number of shoots produced. Shoot explants from A2 accession and node explant from B3 accession produced shoots with the highest average number of chitosan concentrations of 125 and $75 \mathrm{mg} / \mathrm{l}$, respectively.

\subsection{Effect of elicitors on shoot height}

The shoot height response to chitosan elicitor varied with the origin of accession and type of explant. Shoot height produced by shoot tip explants that produced by node explants. Accession A2 from Sampang, Madura still showed the best shoot height
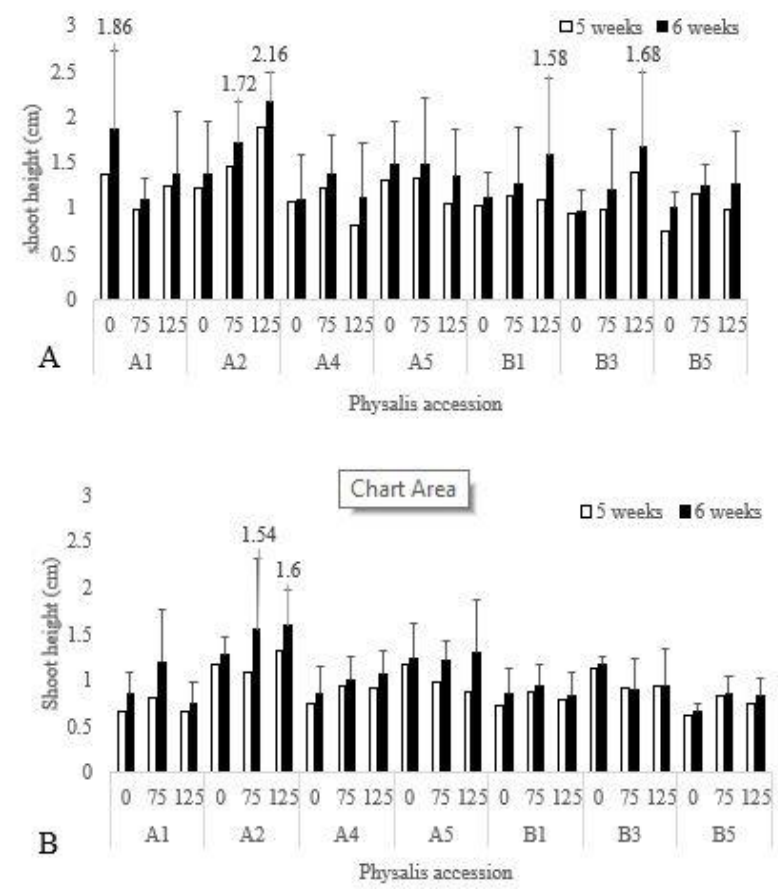

Figure 3. Effect of elicitor chitosan on in vitro shoot height of seven Physalis accession at 5 and 6 weeks after culture. A. Shoot explant, B. Nodal explants. A1: Sumenep, A2 and A4: Sampang, A5: Pamekasan, B1: Tulung agung, B3: Kediri dan B5: Banyuwangi; Chitosan concentration: 0,75 and $125 \mathrm{mg} / \mathrm{l}$.

growth on both shoot tip explants $(2.16 \pm 0.32 \mathrm{~cm})$ and node explants $(1.6 \pm 0.37 \mathrm{~cm})$. Other accessions, although many showed a positive response to chitosan elicitor, but the height was not more than 1.5 cm (Figure 3).

The growth response both quantitatively and qualitatively showed that all Physalis plant accessions in vitro were still able to grow well on the medium with the addition of chitosan elicitor to a concentration of $125 \mathrm{mg} / 1$. Shoot explants are apical shoots which have a growing tip so that the mineral nutrients and exogenous growth regulators supplemented into the medium are immediately used to continue their growth. Apparently, nodal explants still need time to induce the emergence of axillary shoots so that in the same culture age, the resulting shoots are less and still small compared to shoots produced by shoot tip explants.

Chitosan is an elicitor which derived from the component of fungal cell walls [15]. The positive effect of chitosan on in vitro propagation has been proved in some medicinal plants [16][17][18]. Elicitors are chemical substances which has positive effect on in vitro shoot growth [19]. The positive 
effect is also thought to be due to the combination of BAP cytokinins and chitosan elicitors [20].

\section{CONCLUSION}

All plant accessions of Physalis could regenerate and multiply shoots in vitro both without and with the addition of chitosan elicitor. Accession A2 obtained from Sampang, Madura Island resulted in better shoot growth than other accessions. The ability to grow in the elicitation medium provides an opportunity to identify the quantitative and qualitative profiles of secondary compounds.

\section{AUTHORS' CONTRIBUTIONS}

BW contributed to the initiation of the Physalis plant accession seed collection in the field. JB conducted field research, analyzed data, and compiled a draft publication. RM configures a research project. RM also read, reviewed, and contributed to the finalization of the manuscript.

\section{ACKNOWLEDGMENTS}

This work was supported by Faculty of Mathematics and Natural Sciences through the NonTax State Revenue Fund (PNBP) Brawijaya University in accordance with the Brawijaya University Budget Implementation List (DIPA) DIPA-023.17.2.677512 / 2020.

\section{REFERENCES}

[1] F. Mirzaee, A.S. Hosseini, R. Askian, M. Azadbakht, Therapeutic Activities and Phytochemistry of Physalis Species Based on Traditional and Modern Medicine, Research Journal of Pharmacognosy 6(4) (2019) 79-96. DOI: https://doi.org/10.22127/rjp.2019.93529.

[2] N. Mazova, V. Popova, A. Stoyanova, Phytochemical composition and biological activity of Physalis spp.: A mini-review, Food Science and Applied Biotechnology 3(1) (2020) DOI:

https://doi.org/10.30721/fsab2020.v3.i1.80.

[3] E. Shenstone, Z. Lippman, J. van Eck, A review of nutritional properties and health benefits of Physalis species, Plant Foods for Human Nutrition 75(3) (2020) 316-325. DOI: https://doi.org/10.1007/s11130-020-00821-3.

[4] A. Nadhifah, Suratman, A. Pitoyo, Kekerabatan fenetik ciplukan (Physalis angulata L.) di wilayah eks-Karesidenan Surakarta berdasarkan karakter morfologis, palinologis dan pola pita isozim [Phenetic relationship among ciplukan (Physalis angulata L.) in Surakarta based on variation, Jurnal Tumbuhan Obat Indonesia 9(1) (2016) 1-10.

[5] W. Afriani, Eksplorasi dan identifikas morfologi tanaman ciplukan (physalis angulata L.) di kecamatan limapuluh kota sumatera barat. Universitas Andalas, 2018.

[6] E. Effendy, R. Respatijarti, B. Waluyo, Keragaman genetik dan heritabilitas karakter komponen hasil dan hasil ciplukan (Physalis sp.), Jurnal Agro, 5(1) (2018) 30-38. DOI: https://doi.org/10.15575/1864. [In Bahasa Indonesia]

[7] B. Ncube, J. van Staden, Tilting Plant Metabolism for Improved Metabolite Biosynthesis and Enhanced Human Benefit, Molecules, 20(7) (2015) 12698-731. DOI: https://doi.org/10.3390/molecules200712698.

[8] P. Shakya, G. Marslin, S. Karthik, B. Ludger, F. Gregory, Elicitation as a tool to improve the profiles of high - value secondary metabolites and pharmacological properties of Hypericum perforatum, Journal of Pharmacy and Pharmacology 71 (2019) 7-28. DOI: https://doi.org/10.1111/jphp.12743.

[9] S.R. Rao, G.A. Ravishankar, Plant cell cultures: Chemical factories of secondary metabolites, Biotechnology Advance, 20(2) (2002) 101-53. DOI: https://doi.org/0.1016/s07349750(02)00007-1

[10] A. Ramakrishna, G.A. Ravishankar, Influence of abiotic stress signals on secondary metabolites in plants, Plant Signaling \& Behavior 6(11) (2011) 1720-1731. DOI: https://doi.org/10.4161/psb.6.11.17613.

[11] M. Narayani, S. Srivastava, Elicitation: a stimulation of stress in in vitro plant cell/tissue cultures for enhancement of secondary metabolite production, Phytochemistry Reviews 16 (2017) 1227-1252. DOI: https://doi.org/10.1007/s11101-017-9534-0.

[12] C. Gao, R. Li, M. Zhou, Y. Yang, L. Kong, J. Luo, Cytotoxic withanolides from Physalis angulata, Natural Product Research 32(6) (2018) 676-681.

DOI: https://doi.org/10.1080/14786419.2017.1338281 
[13] R. Mastuti, M. Rosyidah, In Vitro Environmental Stresses for Enhancing Withanolides Production in Physalis angulata L., IOP Conference Series: Earth and Environmental Science 239(1) (2019). DOI: https://doi.org/10.1088/17551315/239/1/012011.

[14] R. Mastuti, B. Waluyo, J. Batoro, Response of seed germination and seedling growth of Physalis accession from East Java, ournal of Physics: Conference Series 1563(1) (2020) DOI: https://doi.org/10.1088/17426596/1563/1/012009.

[15] M. Ferri, A. Tassoni, Chitosan as elicitor of health beneficial secondary metabolites in in vitro plant cell cultures, In: Handbook of Chitosan Research and Applications, R. G. Mackay, J. M. Tai (Eds), no. February, pp. 389413, 2011.

[16] F. Abraham, A. Bhatt, C. Keng, G. Indrayanto, S. Sulaiman, Effect of yeast extract and chitosan on shoot proliferation, morphology and antioxidant activity of Curcuma mangga in vitro plantlets, African Journal of Biotechnology 10(40) (2011) DOI: https://doi.org/10.5897/AJB10.1261.

[17] J.C. Cardoso, M.E.B.S. de Oliveira, F. de C.I. Cardoso, Advances and challenges on the in vitro production of secondary metabolites from medicinal plants, Horticultura Brasileira 37(2) (2019) 124-132. DOI: https://doi.org/10.1590/s0102-053620190201.

[18] A.A. de Carvalho, S.K.V. Bertolucci, A. da C. Honorato, T.T. Rocha, S.T. Silva, J.E.B.P. Pinto, Influence of light spectra and elicitors on growth and ascaridole content using in vitro cultures of Dysphania ambrosioides L., Plant Cell, Tissue and Organ Culture 143(2) (2020) 277-290. DOI: https://doi.org/10.1007/s11240020-01892-5

[19] M. Bayraktar, E. Naziri, I.H. Akgun, et al., Elicitor induced stevioside production, in vitro shoot growth, and biomass accumulation in micropropagated Stevia rebaudiana, Plant Cell, Tissue and Organ Culture 127 (2016) 289300. DOI: https://doi.org/10.1007/s11240-0161049-7

[20] S. Govindaraju, P.I. Arulselvi, Effect of cytokinin combined elicitors (1-phenylalanine, salicylic acid and chitosan) on in vitro propagation, secondary metabolites and molecular characterization of medicinal herbColeus aromaticus Benth (L), Journal of the Saudi Society of Agricultural Sciences 17(4) (2018) 435-444. DOI: https://doi.org/10.1016/j.jssas.2016.11.001 